\title{
Disability and Life Satisfaction Scale
}

Gislene Farias de Oliveira ${ }^{1}$; Thércia Lucena Grangeiro Maranhão $^{2}$; Hermes Melo Teixeira Batista ${ }^{3}$; Symara Abrantes Albuquerque de Oliveira Cabral ${ }^{4}$.

\begin{abstract}
Life Satisfaction is a significant indicator of subjective wellbeing. It is assessed as a single, global measure or as a reference related to important areas of life, such as family and work. Assessing life satisfaction in people with special needs and verifying how this construct correlates with demographic variables such as gender, age and schooling, for example, was the objective of this study. Data collection was performed through a questionnaire with a Life Satisfaction Scale. The sample consisted of 48 people from Juazeiro do Norte in Ceará, aged 14-71, mostly male (60.4\%). The results revealed that in $70.9 \%$ of respondents believe that their life is close to ideal in most aspects and that $72.9 \%$ agree that they are satisfied with their lives as it is. $41.7 \%$ reported that the conditions of their lives are excellent. Men said they were more satisfied with life than women, as well as older people and more religious people. Conclusion: This study demonstrated that the loss of certain abilities, such as walking for example, does not seem to cause great changes in the feeling of life satisfaction in the studied population.
\end{abstract}

Keywords: disability, life satisfaction, citizenship

\section{Introduction}

Welfare, as well as people's working conditions, especially those with special needs, are a precarious reality that worries researchers from different countries (Pavarini \& Neri, 2000, Resende, Cunha, Silva \& Sousa, 2007; Cardozo \& Silva, 2014). There were few studies with this particular population. Studies on physician life satisfaction, generally done through the Canadian Medical Association, revealed that $65 \%$ of them reported being dissatisfied with their lives, more specifically with their work (Sullivan, Buske, 1998; Oliveira et al. , 2009).

In Brazil, this population, specifically, still demands studies on the subject. A survey of Life Satisfaction in people with limb amputation, with 21 adults, aged between 42 and 62

\footnotetext{
${ }^{1}$ Faculty of Medicine of Cariri, Ceará, Brazil. gislenefarias@ gmail.com;

${ }^{2}$ Psychologist, Graduated from the Faculty of Human Sciences of Recife - ESUDA, Specialist in Management of Work and Education in Health by the School of Public Health of the State of Ceará. Graduated from the Faculty of Medicine of ABC, Health. Professor of the University Center Dr. Leão Sampaio, Member of the Research Ethics Committee of UNILEÃO. Coordinator of the Cariri Nucleus of ABRH-CE. thercia@leaosampaio.edu.br;

${ }^{3} \mathrm{PhD}$ student in Faculty of Medicine of ABC, São Paulo, Brazil. hermesmelo@oi.com.br;

${ }^{4} \mathrm{PhD}$ student in Faculty of Health Sciences of Santa Casa da Misericórdia, São Paulo, Brazil. symara_abrantes@hotmail.com
} 
years, in the city of Uberlândia, revealed that the interviewees presented Satisfaction with their Health, Physical Capacity, Mental Capacity and Social Involvement, with a higher Satisfaction with Mental Health and Satisfaction with Life 5 years ago (Resende, Cunha, Silva and Sousa, 2007).

\section{Subjective well-being and Life Satisfaction}

The subjective well-being has two main dimensions: one affective, represented by positive (pleasure) and negative (unpleasure) affections, and another cognitive, corresponding to life satisfaction (Pavot et al., 1991). According to Diener et al. (1985), although these components correlate with each other, represent different constructs. Coherently, researchers have identified clearly separate affective and cognitive factors in their measurements (Albuquerque, Troccoli, 2003; Pavot \& Diener, 1993).

Boccolini (2000) believes that the transformations occurring in individuals, due to the loss of capacities, most notably a mutilation, are perceived in a global way, insofar as individuals see themselves in some way less independent, which may cause greater limitations and difficulties in the performance of various daily tasks.

The loss of capacity due to the lack or deficiency of an organ in a person causes suffering abrupt changes in their lives, directly affecting their behavior and the way you act (Botelho et al., 2003). Thus, people with special needs, have the challenge to psychologically adjust somehow the loss of associated capacity, adjust to the disability, which can be potentially disabling and affect the health and well-being of people (Ephraim et al., 2003).

Every adaptation is a process and in the case of adaptation to loss of the ability of any organ of the body, it tends to be gradual and personal. Previous experiences and personal stories of health and illness as well as educational factors, living conditions and the economic resources that allow access to technologies, are, according to Freund \& Baltes (1998), elements that contribute to a more adjusted compensation deficit.

Another aspect observed by Pavarini \& Neri (2000) is that people with physical disabilities can activate adaptation mechanisms to face losses in functionality, both through 
technological resources and psychological and social support. Oliveira (2004), believes that functional impairments may disrupt the individual, to the point of interfering with the performance rules and roles, their independence and ability to perform tasks and in his affective capacity.

To Agree (1999), disability, caused by the loss of a member or organ can be socially defined, and the mismatch of the product between the functional limitation that the individual experiences, environmental demands and expectations regarding the performance of the activities of daily life.

The consequent special need generated by the loss of a physical capacity puts the individual in front of a multiplicity of physical and psychosocial challenges. Since the losses in physical functioning, use of prosthesis, pain, change in employment or occupation, to changes in body image and self-concept. This situation presents itself as a major challenge for the individual to maintain emotional well-being and may generate inappropriate reactions that can lead to a psychosocial maladjustment. However, individual variations in coping with one's own disabilities must be considered. Many individuals can feel emotionally good when they feel supported by a network of relationships (Desmond \& MacLachlan, 2005).

When an individual makes an assessment of one's own life in terms of well-being, that is, when one makes conscious judgments about one's life as a whole or when one makes judgments about specific aspects such as health or one's own body; it can also be done through affection when the individual experiences pleasurable or unpleasant emotions and when he presents a state of humor, he is referring to a multidimensional construct. The subjective well-being (Giacomoni, 2004, Oliveira et al., 2009, Oliveira \& Nunes, 2016).

The subjective well-being is a personal, private experience and its measures include both overall assessment as private ratings referenced fields such as physical and cognitive health, social relationships, family relationships and spirituality. The subjective well-being includes cognitive measures (Life Satisfaction and Satisfaction referenced to more specific domains) and emotional (the most common are the emotional or affective measures, referred to positive and negative values) (Neri, 2001).

According to Freire (2000), life can be satisfactory, with quality and well-being, especially when there is disposition to face the challenges that it proposes to us. This attempt is made easier when the person has a social support network. 
Life Satisfaction is the dimension of interest of the present study. Our goal is with the general assessment that people with special needs make their lives (Diener et al., 1985; Pavot \& Diener, 1993; Oliveira et al., 2009). It gives, therefore, the possibility that they employ their own unique set of criteria to evaluate their quality of life, pondering and giving subjectively different weights to different dimensions you want to take into account.

Life Satisfaction has recently been studied as a cognitive component of subjective well-being (Albuquerque \& Troccoli, 2003, Kim, 2004, Lee, 1998). In the literature, more measures of the affective component of subjective well-being are found (Diener et al., 1985; Pavot \& Diener, 1993; Oliveira et al., 2009). some limitations, such as having a single item, have been built for specific populations (eg children, the elderly) and cover factors other than specifically life satisfaction (Diener et al., 1985). To avoid this limitation, we proposed Life Satisfaction Scale-SWLS (Diener et al., 1985), whose psychometric qualities have already been evaluated for Brazilian samples (Gouveia, et al., 2003 and Oliveira, 2008).

\section{Life Satisfaction Scale}

The Life Satisfaction Scale (LSS) is intended to evaluate how people judge themselves about how satisfied they are with their lives. The measure of satisfaction with life elaborated by Diener et al. (1985), validated for health professionals in the Brazilian Northeast by Oliveira (2008), presents items of a global nature that evaluate the general judgment of the satisfaction that people perceive in their lives. The judgment on what areas to consider about their lives, is the sole discretion of the respondents, taking into account their own interests and values.

It is a unifactorial scale, that is, its items cover only one factor (Life Satisfaction) and has the advantage of being simple and brief (Pavot \& Diener, 1993; Pavot et al., 1991), and can be used (Atienza et al., 2000), adolescents (Atienza, Balaguer \& García-Merita, 2003, Neto, 1993, Pons et al., 2000 and Gilman \& Huebner, 2001), adults (Dirk et al., 1995), the elderly and the elderly (Arrindell, Heesink and Feij, 1999), elderly people (Pavot et al., 1991; Pons et al. ), non-psychiatric medical patients (Arrindell, Meeuwesen \& Huyse, 1991), pregnant women (Martinez et al., 2004) and migrants (Neto, 1993, 2001). 
The LSS has been widely administered in several countries (Pavot \& Diener, 1993), translated into French (Arrindell, Heesink \& Feij, 1999; Arrindell, Meeuwesen \& (Atienza, Balaguer \& García-Merita, 2003), Russian (Balatsky \& Diener, 1993), Arabic (Abdallah, 1998), Czech (Lewis et al. Atienza et al., 2000, Pons et al., 2000, 2002) and even Portuguese (Neto, 1993).

Its factorial structure and reliability were proven in several studies. The factorial analyzes, both exploratory and confirmatory have shown that the five items cover a single dimension (Atienza et al., 2000; Diener et al., 1985; Lewis et al, 1995, 1999,.. Pavot et al, 1991 , Shevlin \& Bunting, 1995). These results demonstrate the suitability of this measure to be valid and need to assess the overall judgment that people make of their satisfaction with life, at least in other countries.

In Brazil, some studies to measure subjective well-being (Albuquerque \& Tróccoli, 2003; Gouveia et al. 2003; Wagner et al., 1999; Oliveira, GF 2008;. Oliveira et al, 2009), used the scale Satisfaction with Life. Despite the quality of the ESV, no Brazilian research was found in which it was used to know satisfaction with the lives of people with special needs.

As was shown above, such a measure covers one of the fundamental components of this well-being: the cognitive. However, researchers, perhaps due to a lack of adequate measures on this component, have insisted on evaluating those affective or emotional, whose means to evaluate them are more present in this country (Gouveia et al., 2003).

Therefore, to adapt it to this context, it is still in a future possibility, given the fact that this study evaluates a still insufficient sample for validation of this construct in the population of people with special needs. This study specifically evaluates the Satisfaction with Life in people with special needs only in the Municipality of Juazeiro do Norte in Ceará.

\section{Method}

This study included 48 people, all carriers of any special needs, except for the mentally handicapped, aged 14 entities and 71 years (mean $40.75 \pm 15.16$ ), the majority were male $(60.4 \%)$. 
Data collection was carried out in Juazeiro of the municipality in the period from July to August 2015. The sample of convenience, since it counted only with the participation of those who were willing to answer.

The main characteristics of the sample are presented below.

There was a certain balance in relation to the age group of the participants, with all the bands being considered. However, the amplitude was very pronounced, from 14 years to 72 years, which tends to reflect in some of the analyzes (minimum $=14$ and maximum $=43$, standard deviation $=5.41)$.

Of the participants, $60.4 \%$ were male and $39.6 \%$ female. As for marital status, $50.0 \%$ are married or live together with a partner; $18 \%$ were single, $1 \%$ Widowed and $5 \%$ were separated at the time of the survey.

With regard to Religion, $60.4 \%$ self-appointed Catholic; $14.6 \%$ Protestant; $6.2 \%$ Spiritist; $2.1 \%$ answered that they have another religion, and $16.7 \%$ do not attend or participate in any religious segment.

Regarding religiosity, $45.8 \%$ consider themselves very religious; $10.4 \% \%$ is considered normal or regular; $18.8 \%$ are not religious; $10.4 \%$ are very unreligious and $14.6 \%$ consider themselves religious.

When it comes to social class, it was observed that $31.2 \%$ are considered low class, $60.4 \%$ middle class and $8.3 \%$ upper class.

Regarding the family income, we observed that the subjects come from very simple homes, considering that the average income of the families does not reach one and a half minimum salary in force.

According to Martins et al. (2001), there is a tendency for women of low socioeconomic status to become more pregnant, have less access to prenatal and supportive services, are more likely to be underweight and / or premature babies, less regularized marriages and, throughout time, tend to accumulate risk factors. Maturano (1997) observed that socioeconomic aspects interfere in the development of the child, as well as consequences of poverty and family structure.

Schooling varied as follows: $41 \%$ did not even complete elementary school; $8.3 \%$ have incomplete secondary education; $27.1 \%$ completed high school, $14.6 \%$ had incomplete higher education and only $8.3 \%$ completed higher education. 
In the case of the employment situation, $29.2 \%$ were employed; $33.3 \%$ were unemployed; $2.1 \%$ left the profession; $22.9 \%$ were retired; $2.1 \%$ were temporarily removed and $10.4 \%$ were in another situation.

As for the special need to change something in the participant relations, $60.4 \%$ answered that they did not observe any significant change and $18 \%$ said yes, that they had changed something in their relations.

The average income of participants varied as follows: $48.0 \%$ said they received up to a current minimum wage; $16.7 \%$ of more than one, up to two current minimum wages; $6.2 \%$ more than two up to three minimum wages in force; $2.1 \%$ more than three up to four current minimum wages; $10.4 \%$ more than four current minimum wages and $16.1 \%$ did not respond to this question.

\section{Instruments}

Participants answered a questionnaire containing two blocks of questions seeking to know the following: (1) satisfaction with life; (2) Socio-demographic characteristics, (3) the impact of special need in the participant's life.

The Life Satisfaction Scale (Diener et al., 1985) is composed of five items that evaluate one of the cognitive components of subjective well-being (for example, in most respects, my life is close to my ideal; living a second time would not change almost anything in my life). Participants give their answers on a 7-point scale, with extremes 1 (totally disagree) and 7 (totally agree). The Brazilian version initially took into account the Portuguese one forwarded by Ed Diener (Neto, 1993), making adjustments in order to make it more culturally appropriate.

The Socio-Demographic Characteristics had the objective of demonstrating a profile of the sample, involving questions such as: Sex, Age, Marital Status, Schooling, Average Income, among others. The Impact of Special Needs on the subjects' lives was obtained through the following questions: Do you consider this need a disability ?; Does the fact that you have a special need change anything in your interpersonal relationships? 


\section{Procedure}

The sites chosen for data collection were: Public Agencies (Schools, Hall); Public squares and eventually residences of individuals, by appointment of the respondents themselves.

\section{Data analysis}

Participants' answers were initially stored in a file from the Statistical Package for the Social Sciences (SPSS 18.0). With this program, descriptive statistical analyzes and decisionmaking were used; uni, bivariate: frequency, percentage, mean and standard deviation; Student's t test (compare mean scores of two groups); ANOVA (Compares mean scores of three groups); the chi-square $\left(\chi^{2}\right)$ to verify if there is a statistically significant difference between observed and expected frequency in contingency tables of categorical variables.

The margin of error in this study is up to five percentage points, plus or minus, with a $95 \%$ confidence interval.

\section{Results}

Table 1 below shows the result of descriptive statistics and differences between sex.

Table 1: Differences between sex and relationship to life satisfaction

\begin{tabular}{lccc}
\hline Sex & Average & Standard deviation & $\boldsymbol{t}$ of student \\
\hline Man & 27,82 & 6,08 & 2,$73 ; 0,009$ \\
\hline Woman & 21,37 & 10,31 & \\
\hline
\end{tabular}

Note: Significant for $\mathrm{p}<0,05$.

The subjects exhibited an average life satisfaction $25.27(\mathrm{SD}=8.54)$, which was above the theoretical median total scale score $(M=15$; range 5-35), $t=2.73, p<0.05$. 
This appears to have been affected by the gender of the Handicapped. Men $(\mathrm{M}=$ 27.82, $\mathrm{SD}=6.08)$ were more satisfied with their lives than women $(\mathrm{M}=21.37, \mathrm{SD}=10.31)$, for $\mathrm{t}=2.73$ and $\mathrm{p}<0.05$.

We try to relate Age and Satisfaction with Life. Because of the sample size $(<200$ subjects), a Pearson $r$ correlation (bi-caudal) was performed, between Age and the total Satisfaction with Life score. At the opportunity, there was no statistical significance ( $r=-$ $0.14, \mathrm{p}>0.05)$, and it could be interpreted as a trend that, the older the person with special needs, the less well-being she experiences. It can be seen from the descriptive statistics of age that there is a great deal of variability among a few subjects $(n=48$, range $=14$ to 71 years, $\mathrm{M}=41$ and $\mathrm{SD}=15$ ). If we increase the size of the sample, it is possible that the significance can be corroborated by this trend.

Regarding whether or not to consider, Carrier of Special Needs did not influence the Satisfaction with the Life of the Participants. Likewise with the fact that the Special Need changes or not, something in the life of the participants and Satisfaction with life. In none of the cases was there statistical significance to corroborate this hypothesis.

As for the role of the Social Class in the Satisfaction with Life scores, through a variance analysis (ANOVA), Scheffe's post hoc test ( $\mathrm{p}<0.05)$ was lower than the means of the social class subjects (18.53) and higher in Life Satisfaction in those with a higher social class (28.50). In short, the higher the social class, the greater the Satisfaction with Life of People with Special Needs.

By ANOVA analysis there was no significant difference between how much it is religious and satisfaction with life. That is, it was found no significant interaction effect between these two variables $(F=0.06 ; p>0.05)$ in this case Handicapped sample.

\section{Discussion}

The main objective of this study was to know satisfaction with life in a sample of people with special needs from the Brazilian version of the LSS (Diener et al., 1985), and is expected to have been achieved. As stated in the introduction, this is a widely used measure in several countries, considering varying samples (Pavot \& Diener, 1993; Oliveira et al., 2009). 
However, no information was found in Brazil about its use to know the satisfaction that the Carriers of Special Needs present with their lives.

Although there is no random sample that can faithfully represent the characteristics of the population of Special Needs Persons in Brazil, an effort was made to constitute a group of people with these characteristics in the Municipality of Juazeiro do Norte, state of Ceará. In this sense, it is hoped to be offering a contribution to the understanding of Life Satisfaction of this part of the population. The main results are shown below.

\section{Life Satisfaction, sex and age}

Despite the adverse working conditions that special needs workers seem to face, the people who made up the sample of this population group reported that they were satisfied with their lives.

The results showed that $70.9 \%$ of respondents believe that in most aspects, their life is close to the ideal and that, $72.9 \%$ of the subjects agree that they are satisfied with their life the way it is and $41.7 \% \%$ of respondents stated that the conditions of their lives are excellent.

Their average score $($ mean $=25.2)$ is within the range which allows to classify them as slightly satisfied (21 to 25 points) (Pavot \& Diener, 1993).

Regarding the answers given to each of the five items of this measure, the highest averages, in terms of agreeing fully, checked for items 3: I am satisfied with my life and 4: Within the possible I have achieved important things What I want from life. The content of these items probably reflects the sense of self-realization. Certainly, it is not limited to any material assets obtained, since, as we also saw, items 2 (The conditions of my life are excellent) and 5 (If I could live a second time, would not change almost anything in my life) were systematically the who received lower scores.

Satisfaction with life was affected by the gender of the Handicapped. Men $(M=27.82$, $\mathrm{SD}=6.08)$ were more satisfied with their lives than women $(\mathrm{M}=21.37, \mathrm{SD}=10.31)$, for $\mathrm{t}=$ 2.73 and $\mathrm{p}<0.05$. This result was consistent with that found in previous research that considered several sample groups (Arrindell, Heesink \& Feij, 1999; Shevlin, Brunsden \& Miles, 1998; Pavot, Diener, 1993; Oliveira et al., 2009; Oliveira \& Nunes, ). 
The life satisfaction score did not vary according to the age of the participants. Specifically some studies consider that older people have greater satisfaction with life (Ehrlich \& Isaacowitz, 2002). It is possible that the sample size ( $<200$ subjects) influenced the results.

Regarding satisfaction with life and social class, there was a higher average in satisfaction with life in social class group higher $(\mathrm{M}=28.50)$ and lowest averages in the group self-appointed lower social class $(M=18.53)$. Ehrlich and Isaacowitz (2002) have shown that people of higher social class experience greater satisfaction with their lives due to the fact that, in general, they tend to enjoy personal stability and fulfillment, which allows them even greater optimism about life.

\section{Conclusion}

In summary, there were indications that the impact of the loss of some capacities caused by the special need did not imply great emotional changes in terms of satisfaction with life in the studied population. However, new studies are recommended in which they can use a larger universe of subjects, including a greater variety of Special Needs, such as lack of vision, and de-muddism, for example, since almost all participants in this research had motor impairment.

Social relations, networks of relationships and social support are current topics of Psychology, especially with regard to the contributions that this science can give to Welfare and Satisfaction with People's Lives (Oliveira \& Nunes, 2016). We believe that future studies that use the argument in favor of the idea that social relations can, in various ways, promote better health conditions, can clarify more about the subject of Life Satisfaction in People with Special Needs. According to Ramos (2002), the help received and the help given contribute to a sense of personal control, and this has a positive influence on people's well-being and Life Satisfaction. 


\section{References}

Abdallah T. (1998). The Satisfaction With Life Scale (SWLS): Psychometric properties in an Arabic-speaking sample. International Journal of Adolescence and Youth, 7: 113-9.

Agree, E.M. (1999). The influence of personal care and assistive devices on the measurement of disability. Soc. Sci. Med., 48, 427-443.

Albuquerque AS, Tróccoli BT. (2003). Desenvolvimento de uma escala de bem-estar subjetivo. Psicologia: Teoria e Pesquisa, 20: 153-64.

Arrindell WA, Heesink J, Feij JA. (1999). The Satisfaction With Life Scale (SWLS): Appraisal with 1700 health young adults in The Netherlands. Personality and Individual Differences, 26: 815-26.

Arrindell WA, Meeuwesen L, Huyse FJ.(1991). The Satisfaction With Life Scale (SWLS): psychometric properties in a non-psychiatric medical outpatients sample. Personality and Individual Differences, 12: 117-23.

Atienza FL, Balaguer I, García-Merita M. (2003). Satisfaction With Life Scale: analysis of factorial invariance across sexes. Personality and Individual Differences, 35: 1255-60.

Balatsky G, Diener E. (1993). A comparison of the well-being of Soviet and American students. Social Indicators Research, 28: 225-43.

Blais MR, Vallerand RJ, Pelletier LG, Briere NM. (1990). L'echelle de satisfaction de vie: Validation canadienne-francaise du "Satisfaction With Life Scale". Canadian Journal of Behavioural Science, 21: 210-23.

Boccolini, F. (2000). Reabilitação - amputados - amputações - próteses. $2^{\mathrm{a}}$ ed. São Paulo: Editora Probel.

Botelho, N.L.P.; Volpini, M. e Moura, E.M. (2003). Aspectos psicológicos em usuários de prótese ocular. Arq. Bras. Oftalmol., 66, 637-646.

Bruce S. (2004). Physician burnout: a pilot study. New Zealand Medical Student Journal, 1: 14-9.

Cardozo, Carolina Garcia; Silva, Leticia Oliveira Silva. A Importância do Relacionamento Interpessoal no Ambiente de Trabalho. Interbio. v.8 n.2, Jul-Dez, 2014

Desmond, D.M. e MacLachlan, M. (2005). Coping strategies as predictors of psychosocial adaptation in a sample of elderly veterans with acquired lower limb amputations. Soc. Sci. Med. (no prelo), Corrected Proof, Available online 28 June 2005.

Diener E, Emmons RA, Larsen RJ, Griffin S. (1985). The Satisfaction With Life Scale. Journal of Personality Assessment, 49: 71-5, 1985. 
Ehrlich BS, Isaacowitz DM. (2002). Does subjective well-being increase with age? Perspectives in Psychology, 5: 20-6.

Fouquereau e, Rioux L. (2002). Elaboration de l'Echelle de Satisfaction de Vie Professionnelle (ESVP) en langue francaise: une demarche exploratoire. Canadian Journal of Behavioural Science, 34: 210-5.

Freire, S.A. (2000). Envelhecimento bem- sucedido e bem- estar psicológico. Em: Néri, A.L. e Freire, S.A. (Orgs.), E por falar em boa velhice (pp. 21-31). Campinas: Editora Papirus.

Freund, A.M. e Baltes, P.B. (1998). Selection, optimization, and compensation as strategies of life-management: correlations with subjective indicators of successful aging. Psychol. Aging, $13,531-543$.

Gouveia VV, Chaves SS, Oliveira ICP, Dias MR, Gouveia RSV, Andrade PR.(2003). A utilização do QSG-12 na população geral: estudo de sua validade de construto. Psicologia: Teoria e Pesquisa, 19: 241-8.

Kim D-Y. (2004). The implicit life satisfaction measure. Asian Journal of Social Psychology, 7: $236-62$.

Lee S. (1998). Marital status, gender and subjective quality of life in Korea. Development and Society, 27: 35-49.

Lewis CA, Shevlin ME, Smekal V, Dorahy MJ. (1999). Factor structure and reliability of a Czech translation of the Satisfaction With Life Scale among Czech university students. Studia Psychologica, 41: 239-44.

Martínez JC, Martínez MR, Garcia JC, Cortes IO, Ferrer AR, Herrero BT. (2004). Fiabilidad y validez de la Escala de Satisfacción con la Vida de Diener en una muestra de mujeres embarazadas y puérperas. Psicothema, 16: 448-55.

Neto F. (1993). The Satisfaction With Life Scale: psychometrics properties in an adolescent sample. Journal of Youth and Adolescence, 22: 125-34.

Neto F. (2001). Satisfaction with life among adolescents from immigrant families in Portugal. Journal of Youth and Adolescence, 30: 53-67.

Oliveira, Gislene F.; Barbosa, Genário A.; Souza, Luana E.C.; Costa, Carolina L.P.; Araújo, Rafaella de C.R.; Gouveia, Valdiney V. (200(9). Satisfação com a vida entre profissionais da saúde: correlatos demográficos e laborais. Revista Bioética, 17 (2): 319 - 334.

Oliveira Catiane de, Nunes Maiana Farias Oliveira, Legal Eduardo José, Noronha Ana Paula Porto. (2016). Bem-Estar Subjetivo: estudo de correlação com as Forças de Caráter. Aval. psicol. [Internet]. Ago [citado 2017 Set 26] ; 15( 2 ): 177-185. 
Oliveira, R.A. (2004). O sujeito e o corpo perante a incapacidade Revista Portuguesa de Psicossomática, 1(6),63-67.

Pavarini, S.C.I. e Neri, A.L. (2000). Qualidade de vida na velhice e atendimento domiciliário. Em: Duarte, Y.A. e Diogo, M.J.D. (Orgs.), Atendimento Domiciliário: um enfoque gerontológico. São Paulo: Editora Ateneu.

Pavot W. e Diener E. (1993). Review of the Satisfaction With Life Scale. Psychological Assessment, 5: 164-72.

Pavot W, Diener E, Colvin CR, Sandvik E. (1991). Further validation of the Satisfaction With Life Scale: evidence for the cross-method convergence of well-being measures. Journal of Personality Assessment, 57: 149-61.

Pons D, Atienza FL, Balaguer I, García-Merita ML. (2000). Satisfaction With Life Scale: analysis of factorial invariance for adolescents and elderly persons. Perceptual and Motor Skills, 91: 62-8.

Pons D, Atienza FL, Balaguer I, García-Merita ML. (2002). Propiedades psicométricas de la Escala de Satisfacción con la Vida en personas de tercera edad. Revista Iberoamericana de Diagnóstico y Evaluación Psicológica, 13: 71-82.

Sullivan P, Buske L. (2004). Results from CMA's huge 1998 physician survey point controlled intervention study of management development programs to a dispirited profession. Canadian Medical Association Journal, targeting female physicians. Tese. Faculdade de Medicina, 159, 54-8, 1998. Universidade Uppsala, Suécia.

Resende, M. C.; Cunha, C.P,B, Silva, A P., Sousa, S. J. (2007). Rede de relações e Satisfação com a Vida em pessoas com amputação de membros. Rev Ciências \& Cognição, Vol 10: 164-177.

How to cite this article (APA):

Oliveira, Gislene F.; Maranhão, Thércia L.G.; Batista, Hermes M. T.; Cabral, Symara A.A.de O. (2017). Disability and Life Satisfaction Scale. Am. In. Mult. J., Oct. 2 (3), 3-16.

Received: 5/6/2017.

Accepted: 9/20/2017. 